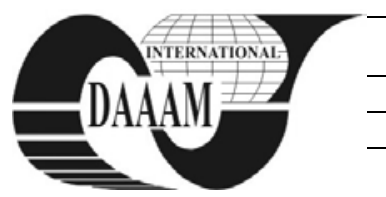

Annals of DAAAM for 2011 \& Proceedings of the 22nd International DAAAM Symposium, Volume 22, No. 1, ISSN 1726-9679 ISBN 978-3-901509-83-4, Editor B. Katalinic, Published by DAAAM International, Vienna, Austria, EU, 2011 Make Harmony between Technology and Nature, and Your Mind will Fly Free as a Bird Annals \& Proceedings of DAAAM International 2011

\title{
LINEAR PROGRAMMING LOCAL COST NUTRITION OPTIMIZATION MODEL
}

\author{
PASIC, M[ugdim]; CATOVIC, A[mra]; BIJELONJA, I[zet] \& CRNOVRSANIN, S[elma]
}

\begin{abstract}
The aim of this paper is to develop a linear programming optimization model of food consumption to meet daily nutrients needs of the standard woman and the standard man at the minimal cost respecting the World Health Organization (WHO) standards. The cost of food, subject to be minimized, is defined as the objective function in the optimization model. The sample used in this research consists of 59 most frequently used food items as decision variables which are selected based on a survey of 50 households in the capital of Bosnia and Herzegovina. Results are obtained in the form of a minimal cost of daily shopping list that will satisfy micronutrient and macronutrient needs.
\end{abstract}

Key words: linear programming, optimization, modeling, cost, nutrition

\section{INTRODUCTION}

Paper (Briend et al., 2001) illustrates how linear programming techniques can be used to determine a nutritionally adequate diet of the lowest cost with an example based on a food price survey performed in Mao, the main city of Kanem Province in Chad for a child aged three to six years. In the analysis, only local traditional food is taken into the model. This research emphasizes benefits of this approach in evaluating the economic benefits of food aid programs.

Study (Maillot et al., 2008) tests the hypothesis how food nutrient profiling ranks may help to identify food with adequate nutrition quality for its price using linear programming model.

Study (Maillot et al., 2009) develops linear programming model which selects an individual weekly diet that meets current nutrient recommendation which approximates person's food intake pattern. Results show that high percentage of adults would need to expand their weekly food repertoire to fulfill nutrient recommendations.

Article (Kopir et al., 2009) shows application of linear programming model to household data in Vihiga district, and determines optimal household consumption bundle of locally available food commodities and the associated expenditures meeting dietary needs. Results show that household incomes are not sufficient to meet nutrient requirements.

Research (Rysiana et al., 2010) investigates the nutrient sufficiency of an adult female in Aceh Besar regency. Results show requirements for minimum food consumption expressed in money value per body mass weekly.

Study (Maillot et al., 2011) develops a linear programming model with age and gender food patterns. The optimized food pattern suggests more vegetables and food intake and lower energy density according to Dietary Guidelines Advisory Committee.

\section{RESEARCH METHODOLOGY}

In this paper linear programming optimization model is developed with the aim to create optimal food shopping list at the minimal cost while meeting micronutrient and macronutrient constraints defined by WHO including energy requirements.

WHO defines human energy requirement as constraint as well. In order to determine individual energy needs a model of standard male and standard female is used. WHO defines standard male person as 25 years old healthy man with an average weight of $65 \mathrm{~kg}$ and low active lifestyle, while standard female person is defined as 25 years old healthy woman with an average weight of $55 \mathrm{~kg}$ and low active lifestyle.

Beside the energy provided by macronutrients such as carbohydrates, fats and proteins, needs for certain types of micronutrients such as vitamins A, C, D, folate, iron, calcium and sodium are taken into consideration. These nutrients are taken into account because lack or excess of these nutrients is associated with the most frequent health problems.

WHO suggests recommended (RNI) and upper limit (UL) nutrient intake as well as recommended energy needs.

The food is divided into 7 major groups according to modified Shermann scheme: 1 . cereals, bread and pasta (including snacks); 2. sugar and sugar concentrates; 3. fat (including nuts); 4. meat, fish and eggs; 5. milk and dairy products; 6 . fruits and 7 . vegetables.

Modification of the Shermann scheme is as follows: snacks are included in the first group, nuts are included in the third group and fruits and vegetables are grouped separately. Optimal division of energy intake should be as follows: $35 \%$ from group $1,10 \%$ from group $2,15 \%$ from group 3, $10 \%$ from group 4 , $15 \%$ from group 5, 7,5\% from group 6 and 7,5\% from group 7 .

Selection of the food commodities used in this research is obtained from a survey of random sample of 50 households in the capital of Bosnia and Herzegovina in February and March 2011. Based on this survey, 59 food commodities are selected as follows: 11 cereals food items, 4 from sugar group, 8 from fats, 7 from meat, fish and eggs group, 9 from milk and dairy products group, 9 from fruits and 11 from vegetables groups.

Retail prices of selected food commodities are taken from major shopping centers in the capital of Bosnia and Herzegovina. Research of the retail prices was conducted in March 2011. Prices are expressed in local currency convertible mark (KM).

\section{MATHEMATICAL MODEL AND RESULTS}

Mathematical model is expected to minimize food cost criteria while fulfilling macronutrient and micronutrient requirements.

Objective function in the developed model is defined by equation (1):

Minimize $Z=C_{1} x_{1}+C_{2} x_{2}+\cdots+C_{i} x_{i}+\cdots+C_{n} x_{n}$

where:

$Z=$ total cost of food identified by model,

$1 \leq i \leq n$,

$n=59$, 
$x_{i}=$ decision variables representing weight of selected food commodity expressed in grams per day,

$C_{i}=$ cost of decision variable $x_{i}$ expressed per unit weight of food commodity.

Constraints in the linear programming model are defined using WHO standards for the recommended and upper limits of daily intake of micronutrients and macronutrients as shown in table 1, and optimal division of energy intake as described above.

Thus the minimization of the objective function is subject to the following constraint nonequalities:

$$
\begin{gathered}
a_{j 1} x_{1}+a_{j 2} x_{2}+\ldots+a_{j i} x_{i}+\cdots+a_{j n} x_{n} \geq(R N I)_{j} \\
a_{j 1} x_{1}+a_{j 2} x_{2}+\ldots+a_{j i} x_{i}+\cdots+a_{j n} x_{n} \leq(U L)_{j} \\
x_{i} \geq 0
\end{gathered}
$$

where:

$j=$ number of a micronutrient or macronutrient shown in table $1, j=1$ to 10

$a_{j i}=$ content of $j^{\text {th }}$ micronutrient or macronutrient per unit weight of $i^{\text {th }}$ food commodity.

Energy intake, as well as optimal division of energy intake constraints, are prescribed as equality.

A standard software package was used to solve developed linear programming optimization model and generate results of the minimization process.

Model results of daily consumption of food commodities according to modified Shermann scheme are given in table 2 .

According to the results of the developed model 3,47 KM for the standard man and 3,38 $\mathrm{KM}$ for the standard woman are calculated as a minimum food cost per day while meeting micronutrient and macronutrient requirements.

Optimal solution for the standard man consists of $15,28 \%$, $3,44 \%, 2,64 \% 8,04 \%, 39,14 \%, 10,92 \%$ and $20,54 \%$ of food commodities of groups 1-7 respectively. Optimal solution for the standard woman consists of $15,26 \%, 3,46 \%, 2,28 \%$, $7,79 \%, 43,43 \%, 7,24 \%$ and $20,54 \%$ of food commodities of groups 1-7 respectively.

Out of 59 food commodities included in the model, optimal solution comprises only 12 for both genders.

\begin{tabular}{|l|c|c|c|c|}
\hline \multicolumn{1}{|c|}{ Nutrients } & \multicolumn{2}{|c|}{ Standard Man } & \multicolumn{2}{c|}{$\begin{array}{c}\text { Standard } \\
\text { Woman }\end{array}$} \\
\hline Energy, kcal/d & $=$ & 2590 & $=$ & 2017 \\
\hline Protein, g/d & $\geq$ & 63 & $\geq$ & 49 \\
\hline Protein, g/d & $\leq$ & 95 & $\leq$ & 74 \\
\hline Carbohydrate, g/d & $\geq$ & 347 & $\geq$ & 271 \\
\hline Carbohydrate, g/d & $\leq$ & 474 & $\leq$ & 369 \\
\hline Fat, g/d & $\geq$ & 42 & $\geq$ & 33 \\
\hline Fat, g/d & $\leq$ & 84 & $\leq$ & 65 \\
\hline Vitamin A, $\mu$ g/d & $\geq$ & 300 & $\geq$ & 270 \\
\hline Vitamin A, $\mu$ g/d & $\leq$ & 600 & $\leq$ & 500 \\
\hline Vitamin C, mg/d & $\geq$ & 45 & $\geq$ & 45 \\
\hline Vitamin C, mg/d & $\leq$ & 1000 & $\leq$ & 1000 \\
\hline Vitamin D, $\mu$ g/d & $\geq$ & 5 & $\geq$ & 5 \\
\hline Vitamin D, $\mu$ g/d & $\leq$ & 50 & $\leq$ & 50 \\
\hline Folate, $\mu$ g/d & $\geq$ & 400 & $\geq$ & 400 \\
\hline Folate, $\mu$ g/d & $\leq$ & 1000 & $\leq$ & 1000 \\
\hline Calcium, mg/d & $\geq$ & 1000 & $\geq$ & 1000 \\
\hline Calcium, mg/d & $\leq$ & 3000 & $\leq$ & 3000 \\
\hline Iron, mg/d & $\geq$ & 8 & $\geq$ & 18 \\
\hline Iron, mg/d & $\leq$ & 45 & $\leq$ & 45 \\
\hline Sodium mg/d & $\geq$ & 1000 & $\geq$ & 1000 \\
\hline Sodium mg/d & $\leq$ & 2000 & $\leq$ & 2000 \\
\hline
\end{tabular}

Tab. 1. RNI and UL micronutrient and macronutrient intake

\begin{tabular}{|c|c|c|}
\hline $\begin{array}{c}\text { Modified Shermann } \\
\text { scheme }\end{array}$ & Standard Man & $\begin{array}{c}\text { Standard } \\
\text { Woman }\end{array}$ \\
\hline Group 1 & $249 \mathrm{~g} / \mathrm{d}$ & $194 \mathrm{~g} / \mathrm{d}$ \\
\hline Group 2 & $56 \mathrm{~g} / \mathrm{d}$ & $44 \mathrm{~g} / \mathrm{d}$ \\
\hline Group 3 & $43 \mathrm{~g} / \mathrm{d}$ & $36 \mathrm{~g} / \mathrm{d}$ \\
\hline Group 4 & $131 \mathrm{~g} / \mathrm{d}$ & $99 \mathrm{~g} / \mathrm{d}$ \\
\hline Group 5 & $638 \mathrm{~g} / \mathrm{d}$ & $522 \mathrm{~g} / \mathrm{d}$ \\
\hline Group 6 & $178 \mathrm{~g} / \mathrm{d}$ & $92 \mathrm{~g} / \mathrm{d}$ \\
\hline Group 7 & $335 \mathrm{~g} / \mathrm{d}$ & $261 \mathrm{~g} / \mathrm{d}$ \\
\hline
\end{tabular}

Tab. 2. Daily consumption of food commodities

\section{CONCLUSION}

The results of this research show that for the standard woman and the standard man it is possible to develop reliable linear programming model which minimizes the cost of food commodities as the objective function while meeting the required micronutrient and macronutrient needs as model constraints.

Limitation of the model is that it is developed for daily needs of the standard woman and the standard man and thus doesn't include food variety consumption as a function of time (time series) as natural human need.

Future research, beside considered micronutrients and macronutrients requirements, should also incorporate more goals in the model like: biological values of food commodities with respect to content of fats, carbohydrates and amino acids, content of antioxidants in food commodities and maximum food budget.

\section{REFERENCES}

Briend, A.; Ferguson, E.; Darmon, N. (2001). Local Food Price Analysis by Linear Programming: A New Approach to Assess the Economic Value of Fortfied Food Supplements. Food and Nutrition Bulletin, Vol. 22, No. 2, (2001) pp. 184189, ISSN 0379-5721

Kopir, M.; Kipsat, M. J.; Nyangweso, P. M.; Otieno, D.; Odunga, P.; Odhiamo, M. O. (2009). Optimal Consumption Bundle for Household Food Security in Vihiga District, Kenya, African Crop Science Conference Proceedings, September 2009, Cape Town, ISSN 1023-070X/2009, Tenywa, J. S. (Ed.), Vol. 9, pp. 739 - 744, African Crop Science Journal, Kampala, Uganda

Maillot, M.; Ferguson, E.; Drewnowski, A.; Darmon, N. (2008). Nutrient Profiling Can Help Identify Foods of Good Nutritional Quality for Their Price: A Validation Study with Linear Programming, American Society for Nutrition Sciences, Vol. 138, No. 6, (June, 2008) pp. 1107-1113, ISSN 0022-3166/08

Maillot, M.; Vieux, F.; Ferguson, E. F.; Volatier, J. L.; Amiot, M. J.; Darmon, N. (2009). To Meet Nutrient Recommendations, Most French Adults Need to Expand Their Habitual Food Repertoire. Journal of Nutrition, Vol. 139, No. 9, (September 2009) pp. 1721-1727, ISSN 00223166

Maillot, M.; Drewnowski, A. (2011). Energy Allowances for Solid Fats and Added Sugars in Nutritionally Adequate U.S. diets estimated at $17-33 \%$ by a linear programming model. The Journal of Nutrition, Vol. 141, No. 2, (February 2011) pp. 333-340, ISSN 1541-6100

Rusyana, A.; Susanti, D.; Ramadhani E.; Nazaruddin, H. (2010). Linear Programming and Sensitivity Analysis for Optimizing Nutrient Sufficiency. Proceedings of the 6th IMT-GT Conference on Mathematics, Statistics and its Applications (ICMSA2010), November 2010, Kuala Lumpur, ISBN 978-983-41743-3-0, Shean, W. (Ed.), pp. 537-551, Universiti Tunku Abdul Rahman, Kuala Lumpur, Malaysia 